\title{
FACTORS THAT CONSTITUTE ROAD TRAFFIC NOISE IN THE NIGERIAN ENVIRONMENT
}

\begin{abstract}
Noise is sound that should not be present where it is not wanted. In an earlier study (Menkiti 1995) it was found that in the Nigerian environnent the kind of noise that hothers people most is the traffic noise. It was decided to explore the ramifications of this type of noise.

Suitable towns and cities were selected in the southern part of Nigeria, questionnaires were adninistered to people for their reactions to aspects of noise and noise measurements were also made. Results of this study reveal thal, among others, traftic noise bothers people more when traffic flow increases; fumes, horns, slamming of vehicle doors add to traffic noise in the perception of people. A wareness to pedestrian danger as a road fraffic actor was found to be low.
\end{abstract}

KEY WORDS: Noise, Traffic, Environment, Awarences

\section{INTRODUCTION}

Sources of stress in our environment are now on the increase. Consequently, concern has been growing about the problem of disturbances emanating from road traffic. An earlier survey made on noise bother (Menkiti 1995) not only conlirmed this but also indicated that, for the population exposed to traffic noise, there is nore to road traffic than just vehicle movement. Usually, it i. adequate to calegorize molor trallic noise into those of motor cycles, cars and heavy (largely commercial) vehicles. The overall noise which is due to the passage of a single motor vehicle arises from a number of identifiable sources which include engine, gears, transmission, fan-cooling system, road-tyre interaction, exhaust and inlet, brakes and aerodynamics (Delancy et al 1976). The relative importance of each source depends on tine size and type of vehicle, on its driven speed. on the load it carrics and on its level of maintenance

When considering traffic noise, one should also bear in mind that there are emissions from the individual vehicles as well as emissions from the overall traffic flow or continuous traffic flow as a whole. in addition to the continuous traffic flow itself. Each of these flows constitutes a part of what the population exposed to road traffic noise cxperiences. To this population, the experience is the sum total effect of the combination of the individual components. The object of this study is to find out the components that constitute road traffic noise in the Nigerian enviromment. to determine whal contribution each makes to the overall traflic noise concept and to evaluate the degree of bother or annoyance created by these components.

\section{METIIODOLOC:Y \\ Site selection}

The lirst stage was to select suitable towns or cilies. Because there were many vartiables envisaged, it was decided (to cut cost and lime) to divide the Country into three zones, North, Middle and South, for the purpose of this study. This pilot study is on the South.

The selection of the cities in this zone was based on areas stratified b y population density. The earlier study guided the choice of the cities finally selected. They were Lagos. Ibadan. Benin. Onitsha, Port Ilarcourt and Uyo.

The second stage was to choose the particular areas of the cities suitalye for study. Although it was appreciated that the study was not going to be based entirely on reactions to physical noise, it was felt that areas on bus routes and those not far from these rovtes would be suitable.

\section{Questionmane \\ Since one $:-$ the main aspects of this

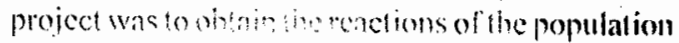 exposed to this noise, a questiomaire was designed. 16 was in thee parts. The lirst part soughty to find out how the respondents feit about their homes. their neighbourlyool and their places of work. They were given the opportunity to indicate particular aspects (Sando et el lo74). In formation was sough from them on how ong they had resided in their homes and neighboumoed, and how long they had worked in an cstablishmem.}

The second part of the perestionmaire. the main one. was directed to road traflic. Pesople were asked about their reactions to aspeets of road traffic which surfaced in the eartier survey. These were noise, vibration, homs, vehicle funres, parking. pedestrian danger, dust. squeal of vehicles, banging on velicles (including door-slimming) and braking. 


\section{TABIE I: TRAFFIC ASSESSMENT OF RESPONDENTS AND INTERVIEW COUNTS OF PEAK HOUR TRAFFIC (VPH)}

\begin{tabular}{|c|c|c|c|c|c|c|c|c|c|c|c|c|}
\hline \multirow{2}{*}{ 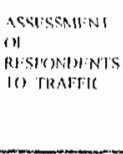 } & \multicolumn{2}{|c|}{ 1.Acios } & \multicolumn{2}{|c|}{$\| B \wedge D A N$} & \multicolumn{2}{|c|}{ ONIISIIA } & \multicolumn{2}{|c|}{ BI:NIN } & \multicolumn{2}{|c|}{ PORT-IIARCYOURT } & \multicolumn{2}{|c|}{ IIYS } \\
\hline & MI:AN & $n / 6$ & MEAN & $\%$ & MEAN & $\%$ & MEAN & $\%$ & MEAN & $\%$ & MEAN & $\%$ \\
\hline $\begin{array}{l}\text { VERY } \\
\text { IIEAVY }\end{array}$ & 600 & 14 & 380 & 18 & 450 & 22 & 390 & 12 & 320 & 15 & 200 & 8 \\
\hline $\begin{array}{l}\text { FAIRLY } \\
\text { III:AVY }\end{array}$ & 300 & 36 & 205 & 17 & 150 & 24 & 200 & 28 & 105 & 10 & 140 & 12 \\
\hline $\begin{array}{l}\text { MODE: } \\
\text { RATI: }\end{array}$ & 150 & 28 & 82 & 34 & 95 & 21 & 120 & 17 & 70 & 19 & 100 & 35 \\
\hline 1, IGIIT & 60 & 11 & 44 & 21 & 55 & 18 & 58 & 29 & 48 & 41 & $5 ?$ & 31 \\
\hline $\begin{array}{l}\text { VERY } \\
\text { LIGHT }\end{array}$ & 27 & 20 & 15 & 8 & 30 & 14 & 32 & 13 & 28 & 14 & 31 & 15 \\
\hline
\end{tabular}

\begin{tabular}{|c|c|c|c|c|c|c|c|c|c|c|c|c|}
\hline \multirow[b]{2}{*}{. } & \multicolumn{2}{|c|}{$\operatorname{ACSOS}$} & \multicolumn{2}{|c|}{$\| M A D A N$} & \multicolumn{2}{|c|}{ ONITSHA } & \multicolumn{2}{|c|}{ BI:NIN } & \multicolumn{2}{|c|}{$\begin{array}{c}\text { PORT } \\
\text { WARCOURT }\end{array}$} & \multicolumn{2}{|c|}{ IIV) } \\
\hline & $A$ & B & $\Lambda$ & B & $\wedge$ & B & $A$ & $B$ & $\wedge$ & B & $\wedge$ & B \\
\hline $\begin{array}{l}\text { \%OF ALL. } \\
\text { RESPONDENTS }\end{array}$ & 40 & 60 & 35 & 55 & 45 & 53 & 40 & 60) & 25 & 75 & 20 & $8 i$ \\
\hline $\begin{array}{l}\text { MEAN VPHIN } \\
\text { PLAK PERIOD }\end{array}$ & 450 & 108 & 290 & 880 & 300 & 90 & 290 & 100 & 200 & 80 & 165 & $8 s$ \\
\hline AVERAGLE & \multicolumn{2}{|c|}{200} & \multicolumn{2}{|c|}{140} & \multicolumn{2}{|c|}{180} & \multicolumn{2}{|c|}{150} & \multicolumn{2}{|c|}{110} & \multicolumn{2}{|c|}{50} \\
\hline
\end{tabular}

The questions wanted to know how much respondents were bothered by eacli of these: Bother here was meant to embrace annoy, worry, trouble, irritate and concern.

The last part of the questionnaire dwelt on the effects of traffic noise on home activities of the respondents. They were encouraged to suggest what remedial actions they believed should be taken to reduce the problem of road traffic noise in their areas.

\section{The Study}

A sample of 200 addresses was taken from each city and one adult was selected from each address. A total of 980 interviews were finally achieved, giving a response rate of $82 \%$.

In addition to the interviews, some physical measurements were macle. The number of vehicles passing in front of an address was counted in two ten-minute periods, one during peak-period condition. Noise levels at these sites (using the same instrumentation as in the survey reported by MENKITI in 1995), the time delay in trying to cross the roads immediately in front of the addresses, as well as the number of parked vehicles around were measured. Some local features were also taken note of; approximate slope of road in relation to a selected address, distance of house from the road, its nearness to a bus route and the type of building.

The percentages of the population exposed to the complex traffic noise who were disturbed by the various components as traffic flowed were oblained. Finally the level of noise excected for $10 \%$ of the time $L_{14}$ was calculated for each city (recording) using the Bruel and Kjaer Noise Level Analyser type 4426.

\section{RESUITS AND DISCUSSIONS \\ Noise Level Result}

Measurements showed that the levels of noise (in $\mathrm{ABA}$ ) depended on the rate of flow of traffic (hence the speed of traffic). on the composition of the traffic (bigger vehicles increase the noise level) and on the gradient (noise level increases with gradient). These results appear to be in agreement with the findings reported by FISK in 1974 and by JOHNSON and SAUNDERS (1968).

The calculated $L_{4,}$ average shows the generally-accepted relationship with mean hourly llow q of

$\underline{L}_{10}=C \log$ a (1MSO 1972)

where $\quad \underline{C}=7.5$ for level roads. and

$=9-12$ for urban conditions (Fisk 1974)

For this study, the relerence levels adopled were $88 \mathrm{~dB} \Lambda$ for heavy vehicles and $82 \mathrm{dBA}$ for others. With these, the experimental $\underline{C}=10.76$, hence for this study $\underline{L}_{1-0}=10.76 \underline{\log q}$

\section{Traffic}

The flow of traffic was based on the tenminute counts multiplied by 6 to give estimates of the number of vehicles per hour (vph). Results show that most people in the areas chosen were 
sulject to flows of traffic, some heavy, some medium and some light. The different results are shown in tables 1 and 2.

\section{Traffic Assessment}

\section{Table 1:}

Table I shows the interviewer counts of mean peai hour traffic in vehicles per hour compared with the Respondent's assessment of traffic. The assessments agree closely with the actual traffic comt in some places and disagrees sharply in others. There is a good agreement in Lagos and Benin and genera! agreement in what constitute moderate, light and very light traffic. This table indicates that in peak perinds vahicle flow is from 27 to 600 per hour in Lagos, 20 to $380 \mathrm{in}$ Ibadan, 30 to 450 in Onitsha, 32 to $390 \mathrm{in} \mathrm{Benim,} 28$ to $320 \mathrm{in}$ Port llarcourt and 31 to 200 in 1 you in the ateas surveyed. It also shows that as lar as heavy tralfic (of 200 velicles per hour) is concened. the respondents exposed are 14\% in Lagos, $18 \%$ in Ibalan. $22 \%$ in Onitsha, $12 \%$ in Benin, $15 \%$ in Port Harcours and $8 \%$ in Uyo. These are really sizeable percentages of the population. Table I confirms the fact that most people in the chosen areas were exposed to flows of traffic. Figure I shows the cumulative distributions of the number of vehicles passing an address in each location at the peak time.

Figure I

In Lagos, about $3 \%$ of those interviewed experienced vehicle flows in excess of $1200 \mathrm{yph}$ as compared to about $1 \%$ in Ibadan, none in Onitsha and about $1.5 \%$ each in Benin, Port I larcourt and Iyo. $400 \mathrm{vph}$ is exporicneed by about $36 \%$ of respondents in lagos, $50 \%$ in lbadan, $35 \%$ in Onitsha, $22 \%$ in Benin, $24 \%$ in Port Harcourt and $34 \%$ in Uyo. A gencral conclusion camnot be drawn from these figures since peak periods varied from cily to city. However, in all the cities surveyed, more than $75 \%$ of the respondents experienced flows of more than 30 vehicles per hour.

\section{Traffic Bothes}

Table 2

Table 2 shows attitudes to traffic bother expericnced by respondents in homes, both along the bus routes and along other routes. It is arranged in sections to show the contributions of the individual parts that make up the complex traffic (noise) bother.

(i)

NOISE

The plots of table 2, figure 2 , indicate clearly that in the zone studied, the percentage of respondents that heard traffic and the percentage bothered by it top the list of all the components. In lagos, the corresponding percentages are 98 and 82 , in lbadan they are 96 and 81. in Onitsha 94 and 88 , in Benin 92 and 87 , in Port Harcourt 98 and 89 and in Uyo they are 71 and 60.

During interviews, it was observed that the decrree of bother or dissatisfaction with noise depended on a number of factors which are largely socio-economic. These range from general standards of environmental acceptability through the attachment a respondent has to
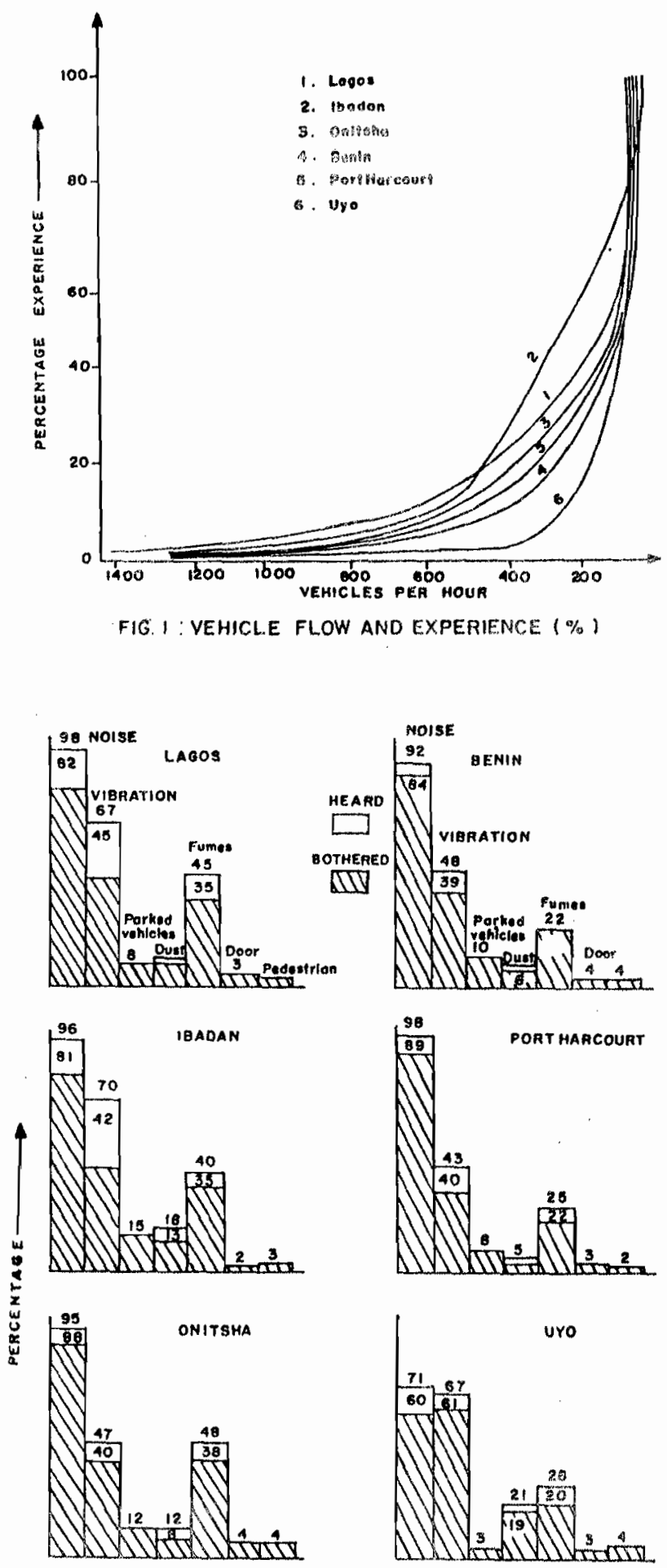

FIG. 2: NOISE SURVEY DUE TO TRAFFIC BOTHER ON BUS ROUTES

the source of the noise to the economic capabilit! it avoiding the noise. These observations are in partual agreement with the findings of LANGOON (Ref. 6).

\section{(ii) VIBRATION}

Noise and vibration are closely related. However, in this study vibration is taken to mean that part of noise which shakes structures, foundations and individuals even when the noise that may have given rise to it is not particularly a bother itself. 


\begin{tabular}{|c|c|c|c|c|c|c|c|c|c|c|c|c|}
\hline $\begin{array}{l}\text { III:ARING IRAFHK } \\
\text { (NOISE:) }\end{array}$ & 98 & 90 & 96 & 90 & 94 & 82 & 92 & 71 & 98 & 88 & 71 & 82 \\
\hline $\begin{array}{l}\text { BOTHHERED BY } \\
\text { TRAFIIC NOISE: }\end{array}$ & 82 & 81 & 81 & 80 & 88 & 76 & 87 & 58 & 89 & 72 & 60 & 48 \\
\hline $\begin{array}{l}\text { FXPPIRIIENCI: } \\
\text { VIIBRATION }\end{array}$ & 67 & 38 & 70 & 32 & 47 & 52 & 48 & 31 & 43 & 38 & 67 & 21 \\
\hline BO THERED & 45 & 18 & 42 & 30 & 40 & 44 & 39 & 21 & 40 & 30 & 61 & 19 \\
\hline $\begin{array}{l}\text { BOTIIERED BY } \\
\text { PARKED VEHHCLISS }\end{array}$ & 8 & 6 & 15 & 3 & 12 & 8 & 10 & 2 & 8 & 17 & 3 & 3 \\
\hline EXPERIENCE DUST & 11 & 17 & 18 & 10 & 12 & 22 & 7 & 20 & 5 & 10 & 21 & 19 \\
\hline BOTHIIERED & 10 & $9^{\circ}$ & 13 & 9 & 8. & 22 & 6 & 17 & 4 & 8 & 19 & 10 \\
\hline I:XPIEIRIINCNI FUMIS & 45 & 14 & 40 & 14 & 48 & 18 & 22 & 17 & 25 & 14 & 28 & 17 \\
\hline BOTHIERS:D & 35 & 12 & 35 & 11 & 38 & 16 & 22 & 16 & 22 & 12 & 20 & 14 \\
\hline $\begin{array}{l}\text { BOTHIIERED BYY } \\
\text { VEIICIEE DOOR } \\
\text { BANGING }\end{array}$ & 3 & 7 & 2 & 2 & 4 & 3 & 4 & 4 & 3 & 4 & 3 & 3 \\
\hline $\begin{array}{l}\text { WOTHERED BY } \\
\text { WANGISR TR } \\
\text { PEDEESTRIANS }\end{array}$ & 2 & 2 & 3 & 2 & 4 & 3 & 4 & 3 & 2 & 2 & 4 & 3 \\
\hline
\end{tabular}

$\begin{array}{ll}A & \text { IN BUIS ROUIES } \\ \text { B } & \text { ONOHILR ROUTES }\end{array}$

Figure 2 shows that the bother due to vibration ranks second to noise. Taking the bus routes, the bother percentages are 45 for Lagos, 42 for Ibadan, 40 for Onitsha, 39 for Benin, 40 for Port harcourt and 61 for Uyo. Apart from Uyo, the average is $42 \%$, high enough for concern since the low frequency effects of waves have been shown to be harmful to the body and to taskperformance (Ref. 8).

Since vibration is transmitted through structures as the traflic flows, one general comment may be that the houses near the bus routes were not well insulated. Concem for this may have been heightened by the suggestion of the danger it poses.

\section{(iii) FUMES}

The levels of bother attributed to fumes from traflic flow are really surprising. These are high in Lagos, Ibadan. Onitsha and Uyo where the percentage bothered ranges from 35 to 20 . These effects are, unlike noise and vibration, felt outside rather than in the homes. Hardly any of the respondents was bothered by fumes in the home. The vehicle identified as causing offence in this respect is the motor cycle mainly with the dieselpowered bus coming a close second.

\section{(iv) DUST}

Dust appears to be present in objectionable quantity in the areas of Lagos, Ibadan, Onitsla and Uyo surveyed. Uyo roads are (at the time of the survey) undergoing a lot of construction, so it is understandable why there is a high percentage of bother for that traffic noise component. It bothers $10 \%$ in Lagos, $13 \%$ in Ibadan, $8 \%$ in Onitsha, $6 \%$ in Benin, $4 \%$ in Port Harcourt and $19 \%$ in Uyo.

\section{(v) PARKED VEHICLES}

The main bother due to parking of vehicles was from the fact that they occupied parts of the road which were already not wide enough. It bothered $8 \%$ in Lagos, $15 \%$ in Ibadan, $12 \%$ in Onitsha, $10 \%$ in Benin, $8 \%$ in Port harcourt and 3\% in Uyo where much parking could not be done due to the road works going on.

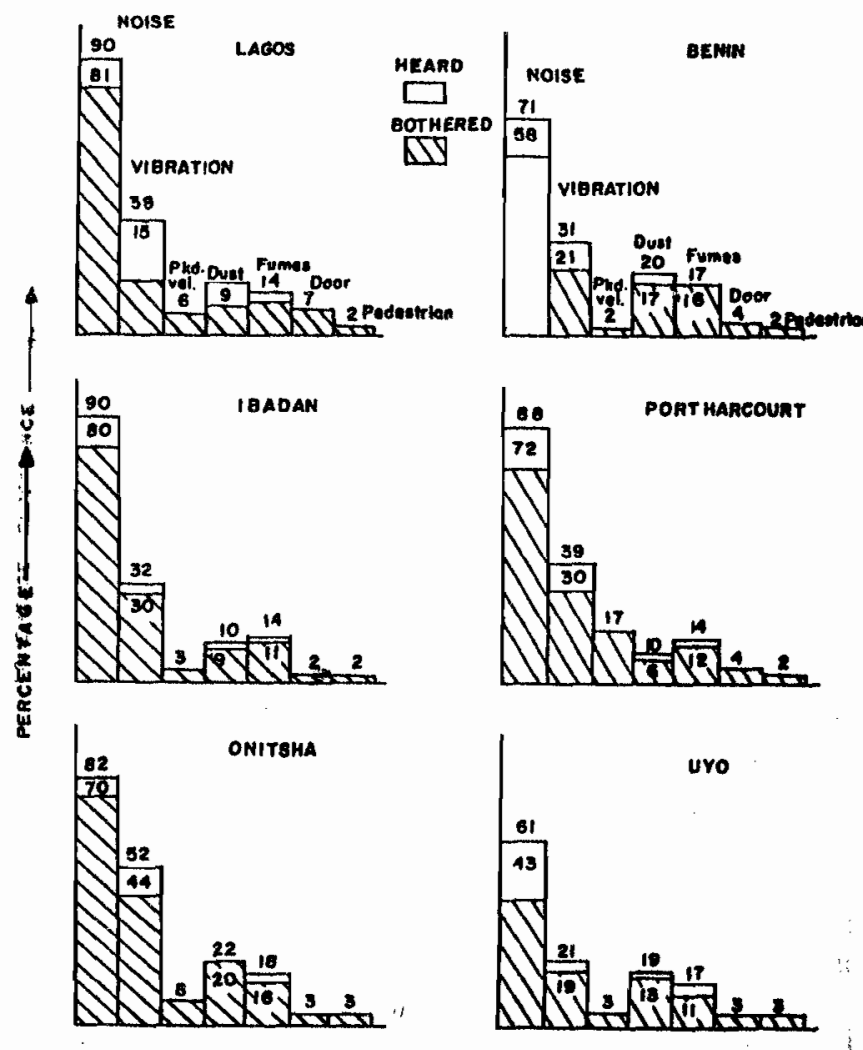

FIG. 3 : NOISE SURVEY DUE TO TRAFFIC BOTHER ON OTHER ROUTES. 


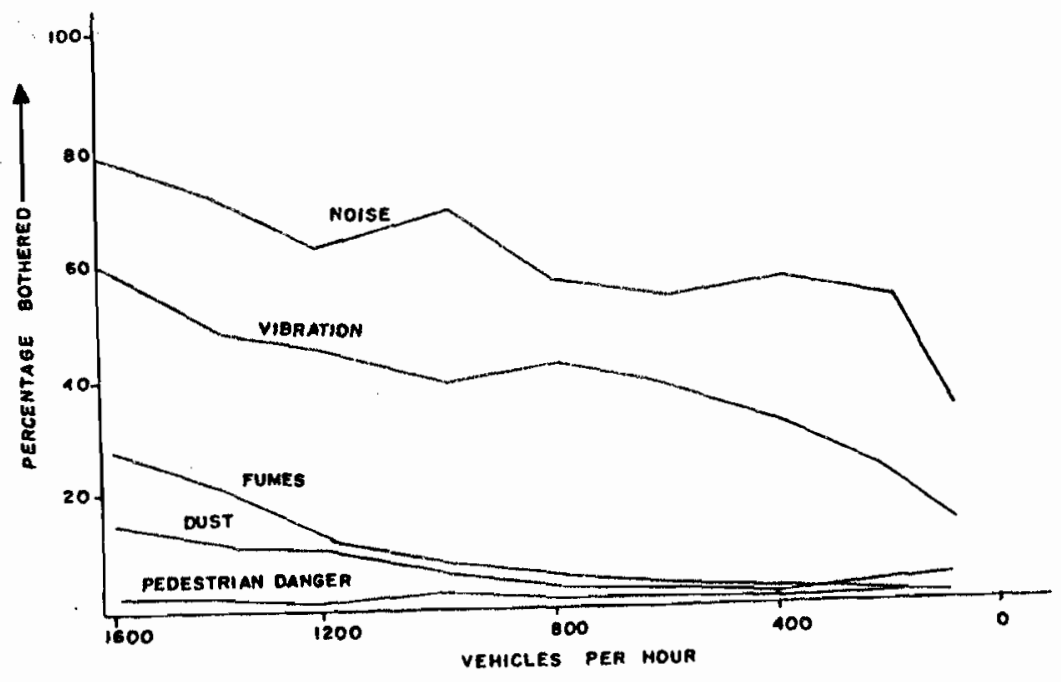

FIG. 4 : PERCENTAGE BOTHER VARIATION WITH VEHICLE FLOW PER HOUR

(vi) VEHICLE DOOR BANGING

This aspect of traffic noise did not really constitute much bother to the exposed population. It did not bother more than $4 \%$ in any city.

\section{(vii) PEDESTRIAN DANGER}

Measurements showed that a fair amount of lime was taken in crossing the roads in front of some addresses. it was therefore a surprise to find that danger-topedestrians was not a source of bother to many people interviewed. Like the vehicles and door-banging, it bothered a maximum of $4 \%$. Part of the explanation may be because there were buses, pedestrian crossing points and accompaniment of children by adults. Part of course may be just that it is not regarded as traffic bother.

\section{FIGURE 3}

The histograms of figure 3 show the attitudes of people on routes other than bus. The trend is similar to that along the bus routes, except that the percentages are comparatively lower.

\section{DISTURBANCE - VEHICLE FLOW}

As was indicated in the study section of the methodology, a correlation was aimed at between percentage of respondents disturbed by the individual components of traffic noise and traffic flow. Figure 3 shows the relationship. Discrete values were obtained for particular flows and these were joined together to give the figure shown.

From the figure, the general trend is that as road traffic flow increases the percentage bother increases - though not linearly. (If a midway line is drawn through the curves, the resulting slopes are 0.03 (Noise), 0.02 (Vibration), 0.02 (Fume) and 0.01 (Dust) giving the impression of a possible empirical relationship between components of road traffic noise and bother.

\section{CONCLUSIONS}

The factors that constitute road traffic noise are complex. They include noise and vibration, fumes from vehicles, dust raised by moving vehicles, noise resulting from opening and closing of vehicle doors. (awkward) parking of vehicles, braking of vehicles, and to a minor extent the danger for pedestrians crossing (busy) roads.

Measurements and surveys show that traffic noise bothers more people more when road traffic flow increased, people are ,botherted more outside their homes.

The disturbance experienced depends on how far the house is from the road and also on the road gradient.

The awareness of pedestrian danger as a road traffic factor is very low.

There appears to be an empirical relationship between road traffic noise components and bother.

\section{REFERENCES}

Delany, M. E. 1974: "Road traffic noise" coustics and Vibration progress Vol. 1 pp. 6-76.

Delany, M.E.,Harland D.G.,Hood, R. A. , and Scholfs, W.E., 1976. The prediction of noise levels $\underline{L}_{11}$ due to road traffic". I. Sound \& vibration, . 48(3): 305-325.

Fisk, D.F., Snith, G.C. and Filton, F. 1974. Prediction of urban traffic noise". Proc. Intern. Congr on Acoustics, Lond. 1: 108.

Itmso, 1972. New housing and road traffic. Dept. of Env. Design Bulletin, 26, 1972.

Johnson, D.R. and Saunders, E.G. 1968. The evaluation of noise from freely-flowing road traffic J. Sound \& Vibration, 7: 287-309.

Langdon, E.J. 1976. Noise nuisance caused by road traffic in residential areas, part 3 . J. Sound and Vibration, 49 (2): 241-256.

Menkiti, A.I. 1995. Analysis of noise bother by survey method, J.W. Afr..Sc. Assoc. 38: 1995.

Menkiti, A.I. and Edet, A.R. 1995. Effects of low frequency noise on some task performances", J.W. Afr. Sc. Assoc. 32: 1995 .

Sando, F.D. and Batty, V. 1974: Road traffic and the environment" Social Trends. No. 5, pp 363. 368 .

Transport and Road Research Lab 1970. A review of road traffic noise Report LR 357: 1970. 